\title{
CAN THE STOCK MARKET ANTICIPATE FUTURE OPERATING PERFORMANCE? EVIDENCE FROM EQUITY RIGHTS ISSUES
}

\author{
Rezaul Kabir \\ Tilburg University, The Netherlands \\ University of Antwerp, Belgium \\ and \\ Peter Roosenboom \\ Tilburg University, The Netherlands
}

February 2001

Keywords: Equity offerings, rights issues, valuation effect, firm performance JEL code: G32, G14

We are grateful to Paul Arts for assistance on this research project. We thank Hans Degryse, Jana Fidrmucova, Kose John, Abe de Jong, Jenke ter Horst, Steven Ongena, Gordon Roberts and seminar participants at University of Antwerp and University of Balearic Islands for helpful discussions and comments. All remaining errors are our responsibility.

Address correspondence to Rezaul Kabir, Department of Finance, Tilburg University, P. O. Box 90153, 5000 LE Tilburg, The Netherlands. E-mail: m.r.kabir@kub.nl 


\title{
CAN THE STOCK MARKET ANTICIPATE FUTURE OPERATING PERFORMANCE? EVIDENCE FROM EQUITY RIGHTS ISSUES
}

\begin{abstract}
$\underline{\text { Abstract }}$
This paper examines whether the stock market valuation impact is consistent with subsequent operating performance of firms. We use data for equity rights offerings - the widely adopted flotation method in the Netherlands. We first examine the stock market announcement effect of rights issues and observe that a statistically significant stock price decline takes place when companies announce rights issues. Further stock price decline is also observed during the subscription period. We then analyze post-rights issue operating performance of firms and find that, consistent with the announcement period decline in stock price, rights issuing firms subsequently exhibit a statistically significant decline in their operating performance. Additional investigation of both stock and operating performance decline provides full support for the information asymmetry hypothesis, partial support for the free cash flow hypothesis but no support for the window of opportunity hypothesis.
\end{abstract}




\section{1. $\quad \underline{\text { INTRODUCTION }}$}

Analysis of corporate security offerings has been an intriguing area of academic research in corporate finance. The topic of equity issues has received the major attention. Eckbo and Masulis (1995) observe that the available empirical evidence is mainly concerned with corporate funding sources, flotation methods and stock market valuation effects of seasoned equity issues. In this study, we address a new but closely related issue. We examine whether the stock market valuation effect observed during the announcement of seasoned equity offerings is consistent with the subsequent operating performance of firms that raised additional equity. The paper thus seeks to contribute further evidence on the forward-looking characteristic of the stock market.

Previous studies mainly based on U.S. data unanimously show that the stock market reacts negatively to announcement of seasoned equity issues. But, studies on equity rights issues have so far produced conflicting results. In a rights issue, corporations wishing to raise additional equity capital distribute certain rights to existing shareholders on a pro rata basis. These rights entitle them to buy a certain number of new shares proportionate to their existing shareholdings at a pre-specified price. Shareholders unwilling to buy these new shares are free to sell their rights in the market during a pre-specified time period. By specifically focusing on companies that use the flotation method of rights offering to raise new external equity, this study adds to the on-going international debate concerning the valuation effect of rights issues.

The paper also contributes to the literature on rights offerings in another direction. Any change in stock price after the issue-announcement, and specifically, during the designated rights trading period is expected to influence shareholders' decisions to sell their rights. Little empirical evidence exists on the stock price behavior during this rights trading period. In this paper, we fill this gap. We also examine the price and the trading volume behavior of rights and analyze the relationship between the announcement period stock return and rights trading. 
To address these issues, we collect data for a sample of equity rights offerings made by Dutch firms and analyze the behavior of stock returns during the announcement period and the rights trading period. We then examine the operating performance of these firms for five years after the offerings. Our results show that a marked decline in stock price takes place when companies announce rights issues. A more detailed analysis did not reveal any contradictory result. Investigating the period of rights trading, we observe that rights are traded actively and stock prices, on average, decline during the subscription period. Next, we investigate the operating performance of companies up to five years after rights issue. We find a significant deterioration in operating performance. Diverse return on assets and return on sales performance measures show that rights issuing firms significantly underperform. Since the result is consistent with the previously obtained announcement period decline in stock returns, we conclude that the stock market has the ability to correctly anticipate subsequent operating performance of firms.

We also investigate the factors that can explain the observed stock and operating performance decline. Our results find statistical support for the asymmetric information hypothesis which argues that corporate managers possess superior information about their firms than outside investors. We also find partial support for the overinvestment of cash flows hypothesis which argues that managers have incentives to invest cash flows in increasing firm size and perquisites. In contrast, there was no support for the window of opportunity hypothesis which argues that corporate managers decide on equity offerings depending on favorable economic conditions.

The remainder of the paper is organized as follows. Section 2 discusses salient features of equity rights issues and summarizes the empirical evidence from recent studies. Section 3 describes the sample and the methodology. The results of the study are presented and analyzed in Section 4 . The section begins by providing summary statistics and analyzing the stock price behavior of rights issuing firms. It then documents post-issue operating performance and tests several hypotheses to explain the observed valuation changes. The last section summarizes the study. 


\section{2. $\quad$ RIGHTS ISSUES}

\subsection{Background}

Listed corporations around the world typically raise additional external equity capital either from existing shareholders or from new investors. The first method is commonly known as rights issue and is widely used in diverse European and international capital markets. A variant of this method is known as standby, insured or underwritten rights issue where an underwriter or a syndicate guarantees to purchase any unsubscribed shares. The second flotation method, commonly known as general cash offers or firm commitment offers, is the usual practice in the United States. It is also common to use the service of an underwriter with this method of flotation. ${ }^{1}$

Marsh (1979), Levis (1995) and Slovin, Sushka and Lai (2000) document that seasoned equity issues in the United Kingdom are predominantly rights issues. Widespread use of rights offerings in many European countries is reported in different studies by De Jong and Veld (2001) for the Netherlands; Gajewski and Ginglinger (1998) for France; Bohren, Eckbo and Michalsen (1997) for Norway; Tsangarakis (1996) for Greece; Loderer and Zimmermann (1988) for Switzerland; and Berglund, Liljeblom and Wahlroos (1987) for Finland. Rights offerings are also observed, although not frequently, in Japan (Kang and Stulz, 1996).

In the United States, on the other hand, rights issues have become a rarity. Smith (1977) and Eckbo and Masulis (1992) observe that although the direct flotation costs of an underwritten equity issue are significantly higher than the costs of a (non-underwritten) rights issue, more than $80 \%$ of equity offerings in the U.S. are, paradoxically, non-rights offerings. In an attempt to explain this paradox, Eckbo and Masulis (1992) and Kothare (1997) argue that some indirect costs like capital gains taxes, transaction costs of selling rights, increased bid-ask spread, etc. are in fact associated with rights issues. But, these

\footnotetext{
${ }^{1}$ Two other closely related flotation methods, known as open offers and placings, have started taking place in the U.K. since the late 1980s (Armitage, 2000; Slovin et al. 2000).
} 
factors seem not to be important enough to deter the frequent use of rights issues in many countries. Besides lower flotation costs, there exist some other explanations for the dominant use of rights issues in these countries. The charter of corporations or stock exchange listing requirements make it obligatory for firms to use rights offerings. Firms' existing shareholders may also want their relative shareholdings to remain unchanged because of control, dilution and other considerations following a equity rights issue. The underwriting syndicate may also have a preference for rights issue because it increases the probability of success of the issue.

In line with other European countries, rights issue is the norm in the Netherlands. Corporate charters provide existing shareholders the pre-emptive right to purchase new issues of common equity. Another special feature is that Dutch firms always adopt standby rights offer method. Thus, investment banks or other financial institutions guarantee the execution of any unexercised rights. The regulation of the Amsterdam Exchanges does not allow listed firms to issue equity without using a financial intermediary. Insured rights offering is also used most frequently in the U.K. The situation is different from the United States and Norway where about $30-40 \%$ of equity rights offers by industrial firms are uninsured rights. ${ }^{2}$

\subsection{Empirical evidence}

Empirical evidence from the United States indicates that stock price declines with the announcement of seasoned equity issues. Jung, Kim and Stulz (1996) report that the announcement of seasoned offerings of common stocks in the U.S. leads to a $3-4 \%$ average abnormal decline in stock prices in a period of two-days. For rights issues in the U.S. a stock price decline is also observed, but the magnitude is found to be smaller. Hansen (1989) reports excess decline of $2.6 \%$ for a sample of 22 industrial underwritten rights offerings. Eckbo and Masulis (1992) document an excess decline of around $1 \%$.

\footnotetext{
${ }^{2}$ Armitage (1998) and Slovin et al. (2000) provide a detailed comparison of institutional settings in the U.S. and the U.K.
} 
On the other hand, non-U.S. evidence on the announcement effect of rights issue is somewhat mixed. Levis (1995) examines 152 rights issues in the United Kingdom and finds a statistically significant two-day excess return of $-1.3 \%$. Slovin et al. (2000) distinguished between insured and uninsured rights issues in the U.K. They find a statistically significant two-day excess stock return of $-2.90 \%$ for 200 insured rights offerings and $-4.96 \%$ for 20 uninsured rights offerings. Gajewski and Ginglinger (1998) also report significant negative excess stock returns associated with rights offerings in France. Analyzing Norwegian data, Bohren et al. (1997) document an insignificant excess return of $-0.4 \%$ for 89 standby rights offerings but a statistically significant positive excess return of $2 \%$ in case of 37 uninsured rights offerings.

In contrast to these findings, Kang and Stulz (1996) observe a significant positive announcement effect (2.2\%) for a small sample of 28 rights issues in Japan. Tsangarakis (1996) investigates 59 rights offering in Greece and also finds a significant excess return of as much as $4 \%$. It is not clear if the positive stock price effect is caused by distinct institutional features of these stock markets like the absence of an active market for rights and highly concentrated / affiliated ownership structure of firms.

A few studies also examine the long-run stock performance after seasoned equity issues. Loughran and Ritter (1995) and Spiess and Affleck-Graves (1995) document significant stock price underperformance over 2 - 5 years following equity issues in the United States. Kang, Kim and Stulz (1999) observe long-run stock price underperformance for Japanese firms issuing equity. Levis (1995) also reports significant long-run stock underperformance from a sample of rights issues in the U.K. Although no generally accepted explanation for these findings exists, there are indications that long-run stock performance measurement is quite sensitive to the econometric estimation technique used. Eckbo, Masulis and Norli (2000) show that methodological improvements lead to the disappearance of any long-run stock price underperformance.

Although the stock market effect of rights issues has received some attention, there is no empirical evidence yet on the operating performance of rights issuing firms. A growing 
body of research has started to examine the operating performance of other types of security offerings. Loughran and Ritter (1997) and McLaughlin et al. (1996) analyzed operating performance of firms conducting seasoned equity issues in the United States. They document that firm performance deteriorates after the offering. In another study, Lee and Loughran (1998) report major decline in operating performance of firms following convertible debt offerings.

\section{DATA and METHODOLOGY}

\subsection{Data}

We compile a list of all seasoned common stock public offerings made by Dutch listed industrial companies between January 1984 and December 1995 from the annual reports of the Amsterdam Exchanges. In total, there were 79 common stock issues out of which $67(85 \%)$ were rights issues. These issues involve 62 different companies spreading over a variety of industries and come from a total of about 170 Dutch industrial companies listed on the Amsterdam Exchanges during that period. The few non-rights equity issues were made jointly on international stock markets and/or related to organizational restructuring.

Due to a different institutional and regulatory environment with respect to financial companies (banks, insurance companies and securities firms), we focus our attention, conforming to the earlier literature, on non-financial firms. Moreover, an analysis of operating performance of financial companies is less meaningful and difficult to compare with those of non-financial companies. The final sample consists of 58 equity rights issues. We collect annual financial statement data of firms for up to five years after rights issues. These data are collected from REACH (a Dutch database available on CD-ROM), and whenever necessary, from Yearbooks of Dutch Companies and company annual reports. $^{3}$

\footnotetext{
${ }^{3}$ We are grateful to Abe de Jong for providing some of these data.
} 
In order to identify the precise announcement date of rights issues, we search the Amsterdam stock exchange publications and the daily Dutch financial newspaper 'Het Financieele Dagblad' (the Wall Street journal of the Netherlands). Daily stock returns are calculated by collecting adjusted share prices from Datastream and cash dividends information from the financial newspaper. Since there exists no database which compiles information on rights trading, we search the newspaper to collect all rights related information. We also hand collect daily rights price and rights trading volume observed during the subscription period.

\subsection{Methodology}

A standard event study methodology is used to measure share price reaction to rights offering announcements. The excess stock return is calculated in two ways: as the differences between the realized return from the return predicted by the Market Model and the return of the Dutch stock market index. The Market Model parameters are estimated over 200-trading days surrounding the event period. We define the event period to be from 60 days before the announcement to 30 days after the announcement. We investigate cumulative excess stock returns for several sub-periods: two-day cumulative excess return for the announcement period; 60-day cumulative excess return for the pre-announcement period; and 29-day cumulative excess return for the post-announcement period. Our null hypothesis is that cumulative average (median) excess stock returns are equal to zero. In order to test whether the cumulative average excess return is significantly different from zero, we perform a conventional t-test based on standardized excess returns. We also perform non-parametric tests such as sign test and Wilcoxon signed rank test.

Similar to stock returns, the operating performance of firms conducting rights issues is examined by analyzing excess measures of operating performance. The procedure of calculating the excess operating performance is as follows. For each issuing firm, and for each year during the period 1984-1999, we first select the universe of all non-issuing listed firms. These non-issuing firms are chosen in such a way that no equity offering, initial 
public offering or seasoned offering, is made by a firm during the preceding five years. The procedure involves selecting a new sample of non-issuing firms in each year. We choose as a match the median operating performance from the control portfolio of all nonissuing firms in that year, and then calculate the difference in performance measure. This difference is denoted as abnormal or excess operating performance. ${ }^{4}$

For each firm in the sample, the operating performance is evaluated by using a wide variety of measures. Four different variants of return on assets (ROA) measures are used at first. These variables are calculated as follows: net income divided by the average of beginning- and ending-period book value of total assets, cash flow (net income plus depreciation plus the change in current assets excluding the change in cash minus the change in current liabilities plus the change in current maturities of long-term debt) divided by the average value of total assets, earnings before interest and taxes (EBIT) divided by the average value of total assets, and earnings before interest and taxes plus depreciation and amortization (EBITDA) divided by the average value of total assets. All these measures are scaled by the average book value of total assets to allow for comparison across firms and through time.

The proceeds of a new equity issue usually results in an increase in cash or other assets. Consequently, the ROA measure for sample firms will probably be lower. Following Barber and Lyon (1996), we, therefore, construct an additional operating performance definition, namely, profit margin or return on sales (ROS). Similar to ROA, we calculate four variants of ROS measures using the average of beginning- and ending-period value of total sales in lieu of total assets. Scaling by total sales has the additional advantage of overcoming the historical cost problem associated with total assets.

\footnotetext{
${ }^{4}$ An improvement of this methodology would be to select firms on the basis of their size, industry or pre-event performance. But, the lack of numerous Dutch listed firms does not allow us to follow any of these approaches.
} 
For all these eight different performance measures, we first calculate levels of abnormal operating performance, and then as a robustness check, calculate year-to-year changes in abnormal performance. The level (change) of operating performance of rights issuing firm is adjusted by subtracting the median level (change) of operating performance of control portfolio of non-issuing firms. In line with previous work, the analysis of the sample operating performance is performed using the median values due to the inherent skewness in operating performance variables (Loughran and Ritter, 1997; McLaughlin et al., 1996). Abnormal operating performance is also cumulated over a period of up to five years after rights issue. For all median values, we determine the statistical significance by calculating the two-tailed Wilcoxon signed-rank test.

\section{4. $\quad$ EMPIRICAL ANALYSIS}

\subsection{Sample characteristics}

Some descriptive information on rights issues and firm characteristics is presented in Table 1. We first provide information on the issue-size and the issue-price. By scaling the monetary amount of rights issue with the market value of common equity on the day before announcement, we find that average rights issue represents $21 \%$ (median $=16 \%$ ) of firm's outstanding common equity. This is roughly similar to U.S. and U.K. rights issues. Analyzing the offer price of rights issues we observe that it is, on average, set below the market price prevailing during the days before the announcement. The average issue-price (subscription price discount) in our sample of rights issues is $88 \%(13 \%)$ with a standard deviation of $10 \%$. This is slightly less than the average offer price discount observed in case of insured rights offerings in the U.S. (20\% reported by Eckbo and Masulis, 1992) and in the U.K. (17\% reported by Slovin et al., 2000). ${ }^{5}$ The average subscription price discount is remarkably higher in Norway (about 50\% reported by Bohren et. al., 1997) and Greece (38\% reported by Tsangarakis, 1996).

\footnotetext{
${ }^{5}$ In the U.S. the offer price is established not at the time of announcement of an equity issue but only at the start of the subscription period.
} 
The size of firms undertaking rights offerings is measured by the book value of total assets and by the market value of common equity. The mean total assets value for rights issuing firms is 623 millions Euros while the median is 178 million Euros. Similarly, the mean stock market capitalization of sample firms is 349 million Euros while the median is 113 million Euros. Wide differences between median and mean values of both total assets and total equity indicate the presence of some large firms in the sample. The average value of market-to-book ratio (defined as end-of-year market value of common equity plus book value of total debt divided by end-of-year book value of total assets) is close to unity. The ratio is quite variable across firms - the minimum in our sample is 0.65 while the maximum is 2.09 .

\subsection{Stock market response}

The stock price reaction to announcements of equity rights offerings is presented in Table 2. Excess stock returns are estimated in two ways: after adjusting for each stock's systematic risk estimated from the Market Model, and after adjusting for the general stock market index. ${ }^{6}$ Our results show that the stock price announcement effect is significantly negative. On the day of the announcement of rights issue (day 0), the average excess decline is about two percent. An additional half a percent decline takes place on the day after the announcement. In two days time, shareholders of rights issuing firms suffer an average abnormal wealth reduction of about $2.8 \%$ (Panel A). The t-value of -7.89 indicates that the two-day cumulative average abnormal return is statistically significant.

Since the sample size is not large, it is useful to calculate median excess returns. The results are reported in Panel B of Table 2. The two-day announcement period median excess return is $-1.76 \%$. The corresponding Wilcoxon signed rank statistic (3.09) indicates that the median return is statistically significant at the $1 \%$ level. We further check and find that $64 \%$ of announcement period excess returns are negative. A sign test shows that the fraction of negative returns is significant at the $5 \%$ level. The finding of a

\footnotetext{
${ }^{6}$ Since the results estimated from both methods are basically the same, we report the riskadjusted excess returns only.
} 
significant stock price decline associated with the announcement of equity rights issue is, therefore, invariant to the different ways of calculating excess returns. Our result is also consistent with that found earlier by Hansen (1989), Levis (1995), Bohren et al. (1997) and Slovin et al. (2000).

The magnitude of the excess stock return attributed to rights issue announcements will be incorrect if these announcements also coincide with confounding events. Therefore, for all rights issues in our sample, we check the financial press to see if other kinds of information releases coincide with issue announcements. We observe that many equity offering announcements are made in conjunction with announcements unrelated to equity offerings, such as earnings increases or decreases, mergers and acquisitions, company restructuring and reorganizations, etc.

Although confounding events can produce a neutral impact when the effects are in opposite directions, we decide to investigate the financial press thoroughly. We find that only nine rights issue announcements are absolutely free from any confounding event. No other material information unrelated to equity offerings is found to be disclosed at the time of rights issue announcements. Even though the sample size in this case becomes very small, it is worthwhile to see if the previously obtained finding from the full sample remains valid. Our analysis shows that a significant stock price decline still takes place when these rights issues are announced (the average decline is $2.56 \%$ in two days). Confounding events do not appear to change the direction of average price reaction obtained from the full sample.

The equity issuing firms intend to use issue-proceeds for several purposes such as new investments, financing takeovers, debt repayment, etc. It is interesting to examine if rights issuing firms with new investment plans exhibit a different stock price reaction compared to firms with other issue-purposes. ${ }^{7}$ Therefore, we analyze a new sample consisting of 18 rights offerings where the financing of new investment projects is cited as the reason of

\footnotetext{
${ }^{7}$ Firms always announce what to do with regard to the use of proceeds from equity offerings. Announcing the purpose of the issue is, therefore, not considered as a confounding event.
} 
new equity issue. We find that these firms with new investment plans also experience a statistically significant average excess decline $(-1.06 \%)$ in their stock price. However, the magnitude of the stock price decline is smaller than that obtained for the total sample.

Overall, the empirical evidence provided in this study suggests that the announcement of rights issues is associated with a significant decline in stock return. The finding is insensitive to one or another stock return estimation procedure or specific characteristic related to rights issues. The result is also consistent with the valuation effect of rights issues documented in several prior studies.

\subsection{Analysis of rights trading period}

We observe in Table 2 that the cumulative excess stock return during the postannouncement period (day +2 to day +30 ) is negative. The mean (median) risk-adjusted excess stock return is $-2.55 \%(-4.08 \%)$. This decline in stock returns indicates that the market receives additional unfavorable information following rights issue announcements. After conducting additional investigation, we find that the issue prospectus is usually published a few days after the announcement of rights issue, and subsequently, the trading in rights starts on the stock exchange. Our analysis reveals that the median number of days from the announcement of rights issue until the start of rights trading is 17. This is in contrast to the practice prevailing in the U.K. where rights trading usually starts on the day the offer is formally announced (Armitage, 2000). U.K. firms are also increasingly adopting open offers, which are similar to rights issues except that the existing shareholders can not sell their rights. In the U.S., on the other hand, rights trading starts six to seven weeks after the announcement (Hansen, 1989). Stockholders have thus several days to decide either to accept the offer of the right or to sell the rights in the market. Stock price development is expected to play an influential role during this time period. Shareholders will evaluate any loss from share price decline with the gain from selling the rights. Those who do not wish to take up their rights are then faced with the decision of when to sell the rights. 
In order to examine rights trading in detail, we hand collect information on daily price and trading volume of 55 rights issues from the financial newspaper. ${ }^{8}$ We observe that the length of the subscription period ranges from a minimum of 6 days to a maximum of 13 days, with a median of 9 . Since the rights trading period varies from firm to firm, the number of available firms in the sample continues to decline drastically towards the end. For a sample of 22 industrial rights offerings in the U.S., Hansen (1989) finds that the length of subscription period varies from 9 to 14 days. Armitage (2000) reports that the rights trading period in the U.K. must last a minimum of three weeks.

Analyzing the behavior of rights price during the offer period, we observe that rights prices are, on average, the highest during the initial days of trading and the lowest towards the end. The period of the initial four days of rights trading is accompanied by cumulative average rights price decline of $6 \%$. It is followed by another cumulative average decline of $16 \%$ during the next four days. We also analyze daily trading volume behavior of rights. Our analysis shows that active rights trading starts from the beginning of the subscription period, and it reaches the highest level at the end. Since investors are not required to disclose their identity, we are unable to find out who buys or sells these rights. Singh (1997) analyzes a sample of rights offerings by public utility companies in the U.S. and finds that underwriters play an active role in the market for rights by purchasing rights in the offer period.

It is interesting to see how stock prices evolve during the period of rights trading. Investors usually evaluate expected changes in both stock price and rights price to decide if they are better/worse off in holding the rights. The analysis of stock returns also allows us to determine if the stock price change is consistent with the earlier observed postannouncement period change in stock returns. We compute, therefore, excess stock returns for up to eight days of rights trading - the period consisting of about $90 \%$ of sample firms. The number of firms with rights trading reduces by $40 \%$ on the ninth trading day and by more than $90 \%$ on the tenth trading day.

\footnotetext{
${ }^{8}$ We are unable to find rights related information in the newspaper for all firms.
} 
The results are reported in Table 3. Day 1 is defined as the first trading day of rights, day 2 is the second trading day, and so on. We find that the cumulative average excess stock return during the eight days of rights trading is $-1.35 \%$. In each but one day the average excess stock return is negative and the majority fraction of firms experience negative stock returns. We also observe that the magnitude of stock price decline is higher on later days, a period coinciding with the highest level of trading volume of rights. Rights trading, therefore, accounts for part of the stock price decline observed during the postannouncement period.

We also explore if the volume of rights trade can explain the announcement period excess return. Intense rights trading indicates that existing stockholders are less willing to exercise their rights. Any such anticipation by the stock market may, in turn, aggravate the decline in stock price. We regress announcement period excess stock return on the cumulative volume of rights traded defined as the total market value of rights divided by pre-announcement stock market capitalization. We conduct univariate and multivariate regressions with different variable definitions. The results, not reported here, show that although the coefficient of rights volume is negative, it is statistically insignificant.

\section{$4.4 \quad$ Operating performance}

So far, we have analyzed the stock market reaction to equity rights issue announcements. We now raise the following question: is the post-issue operating performance of firms consistent with the stock price effect observed during rights issue announcement? Or, stated differently, can the stock market correctly anticipate future changes in firms' operating performance? If raising additional capital by means of equity offerings leads to improvement in firm's performance, then the previously documented negative announcement effect should be considered as an anomalous finding. On the other hand, if stock price changes are considered to be forward looking and correct, then post-rights issue operating performance would show deterioration. We address this issue in the following paragraphs. 
The excess operating performance of firms subsequent to rights issue is reported in Table 4. As mentioned earlier, for each issuing firm, we identify all listed firms without any initial public offering or seasoned equity issue during the preceding five years. Abnormal or excess operating performance is then calculated as the difference in performance between issuing firm and median non-issuing firm. The Table documents median abnormal levels of operating performance for the period beginning with the year of rights issue up to five years after right issue. Panel A presents the results for four Return on Assets (ROA) measures while panel B reports those for Return on Sales (ROS) measures. Overall, the results reveal a clear picture: each of the eight variants of performance measures is negative in post-rights issue years. Many of these excess declines are statistically significant as determined from the Wilcoxon signed-rank statistic. Rights issuing firms systematically experience an abnormal decline in operating performance. The magnitude of different post-rights issue five years cumulative average ROA excess performance measures varies from $-6.2 \%$ to $-9.1 \%$ while that of ROS measures varies from $-1.2 \%$ to $-14.1 \%$. We now explain these results in detail.

In Panel A of Table 4, we observe that all four ROA performance measures during the five years after equity issues are negative. Looking at the performance variable net income / total assets, we find that the median abnormal decline is more than one percent in each of the years 2 - 5. Three of these declines are statistically significant. Similar statistically significant declines are observed in other return on assets variables for the post-rights issue years. The decline in performance is statistically insignificant in the first year after equity issue. As one might expect, it can be too early to notice any significant change in operating performance immediately in year 1 . The results from the two operating income related performance variables (EBIT and EBITDA) also indicate underperformance of firms in each of the five post-issue years.

Turning to Panel B, we observe once again that in each post-rights issue year all excess ROS (or profit-margin) performance variables are negative. The effect is found to be insignificant in the first year after rights issue. The net profit margin (net income / total sales) variable shows statistically significant decline in years 3 and 5 . The median excess 
cash flow margin (cash flow / total sales) in year 2 is $-1.9 \%$ which is statistically significant. The significant deterioration in cash flow margin persists in year 3 . The underperformance of issuing firms is also evident when we evaluate operating profit margin measures. The decline according to the performance metric EBIT / total sales is statistically significant in the third, fourth and fifth year following rights offering. Overall, we find the results using ROS measures qualitatively similar to those of ROA measures.

We check the robustness of above findings by calculating year-to-year abnormal change in operating performance of rights issuing firms. The results are presented in Table 5. In Panel A, the reported median changes in return on assets are negative in the majority of cases during the five years following rights issue. Panel B reports median changes in returns on sales measures. These are also mostly negative. The results being similar to the ones obtained earlier reinforce our finding that rights issuing firms undergo an abnormal decline in their operating performance.

Overall, we document significant negative operating performance of firms after rights issues. The post-rights issue decline in operating performance is also consistent with the negative announcement period stock returns. Our results indicate that the observed value decline in the stock market at the time of announcement of rights issue comes from the expected deterioration in future operating performance of firms. The evidence provided here, therefore, leads us to believe that the stock market can correctly anticipate future operating performance of firms. When we compare our results with those of non-rights equity issues in the United States as reported by Loughran and Ritter (1997) and McLaughlin, Safieddine, and Vasudevan (1996), we observe that our results are quite similar in direction. But, the magnitude of the average decline in operating performance for rights issuing firms is smaller. It corresponds well to the earlier results obtained from stock return analysis which indicates that the magnitude of stock price change is also smaller for firms issuing equity rights. 


\subsection{Explanation of underperformance}

We have, so far, documented a significant decline in stock price with the announcement of equity rights issue and a significant decline in post-issue operating performance of firms. In this section, we investigate the sources that can explain the observed underperformance in stock returns and operating performance. First of all, we consider the leading theoretical explanations put forward in the literature.

\subsubsection{Theoretical explanations}

It is widely believed that company managers know more about their own firm than the stock market because they possess private information on either the value of assets-inplace or investment opportunities. This private information is conveyed to the capital market, either intentionally or unintentionally, in a variety of ways including that of issuing new securities. Myers and Majluf (1984) were the first to show that managers with superior private information have incentives to issue equity when the prevailing market price of shares is larger than their intrinsic value (i.e. the stock is overvalued). Knowing that managers will avoid issuing undervalued shares, investors interpret an equity issue as a signal of overvaluation. This reasoning is formally known in the literature as the information asymmetry hypothesis. ${ }^{9}$

The simplest version of this hypothesis predicts an immediate drop in share price when companies announce new equity issues. The greater the overvaluation (information asymmetry), the higher would be the stock price decline. ${ }^{10}$ A related model developed by Ambarish, John and Williams (1987) argues that the announcement effect of equity

\footnotetext{
${ }^{9}$ In case of rights issues firm's existing stockholders obtain a certain number of rights to subscribe newly issued equity. As long as all these rights are exercised, the argument of information asymmetry should not play a role in rights offerings. However, the fact that existing shareholders sell their rights and new investors buy shares indicates that information asymmetry does play, albeit diminished, role.

${ }^{10}$ The fact that company managers have better information than investors creates an adverse selection problem: as the decision to issue equity results in a loss of firm value, higher quality firms (with valuable investment projects) making equity issues are treated similar to lower quality firms.
} 
issues in fact reflects the source of asymmetric information: value of existing assets or future investment opportunities. According to the model, the negative market reaction to stock issue will be aggravated for low growth firms (these have abundant assets-in-place but limited opportunities to invest) whereas the effect will be mitigated for high growth firms (these have limited assets but abundant opportunities to invest).

A second hypothesis predicting stock price decline associated with equity issue announcement is known as the overinvestment of free cash flows hypothesis (Jensen, 1986). It views that corporate managers prefer to increase the amount of assets under their control even if doing so causes reduction in firm value. They prefer to invest more of firm's free cash flows in 'empire building' and in perquisites instead of distributing these to shareholders. Equity offerings thus convey higher probability of overinvestment of free cash flows on the part of managers. Share price would, therefore, decline because with higher amount of equity capital firms' stockholders are faced with considerably higher agency costs.

Another explanation is provided by the window of opportunity hypothesis which suggests that managers decide on equity issues based on favorable economic conditions like business cycle expansions and hot issue periods (Choe, Masulis and Nanda, 1993; Bayless and Chaplinsky, 1996). Better investment opportunities are available for firms during these periods. Firms will have more possibilities in making investments in high quality (profitable) projects. Stock price reaction is, therefore, expected to be less negative for equity issues announced during good time periods.

\subsubsection{Proxy variables}

In order to investigate the validity of the above hypotheses in explaining the performance of rights issuing firms, we use various proxies for information asymmetry, free cash flows and window of opportunity, and employ different models of cross-sectional regression analyses. We consider two variables to proxy information asymmetry. These are the relative size of rights issue defined as the monetary amount of rights issue divided by the 
market value of firm's equity, and the offer price discount defined as the rights issue price divided by the stock price prevailing before the issue announcement. These two variables represent rights issue characteristics at the time of announcement and are undoubtedly the two most direct and relevant pieces of information for the stock market. If the overvaluation of stock is high, managers of firms are more likely to raise as much new equity capital as quickly as possible. In addition, they are more likely to provide large offer price discount to make the equity issue a success. Since investors are concerned with adverse selection, the information asymmetry hypothesis predicts that the higher the size of an equity issue or the lower the equity offer price (i.e. the higher is the offer price discount), the more negative will be the information signaled to the market, and therefore, the larger will be the decline in performance.

We use the ratio of market to book value of total assets as a proxy for free cash flows. Firms with higher amount of free cash flows are expected to engage more in overinvestments and have, therefore, a lower market to book ratio. If these firms decide to issue additional equity, then they are predicted to experience lower stock returns and lower post-issue operating performance. On the other hand, equity issues undertaken by firms with a higher market to book ratio of total assets would be interpreted as a sign of utilization of new investment opportunities. These firms are expected to undergo improvements in stock and operating performance. It should be noted here that the market to book ratio variable can also proxy for the growth rate of firms the differences in which may reflect information asymmetry. The presence of abundant investment opportunities (high growth) can be associated with higher market to book ratio while firms with abundant assets-in-place (low growth) can have a lower market to book ratio. One can use the $R \& D$ expenditures incurred by a firm as an alternate proxy, but it can also represent firm's growth rate as well as free cash flows. Besides, such data are not available for the majority of our sample firms. ${ }^{11}$

\footnotetext{
${ }^{11}$ Since these and other proxy variables suffer from the same problem, it is empirically very difficult to clearly distinguish the information asymmetry hypothesis from the free cash flows hypothesis.
} 
In order to test the window of opportunity hypothesis which argues that equity issues announced during the period of favorable macroeconomic condition are expected to generate smaller stock price decline, we use several proxy variables. The annual growth rate of gross domestic product, the unemployment rate, the annual change in average stock market prices are used to distinguish good years from bad years. The values of these variables are then used to dichotomize all years in the sample period. The years representing favorable economic condition are identified with the value of 1,0 otherwise.

\subsubsection{Results}

We now proceed to investigate if these three hypotheses can explain the earlier documented decline in stock return and operating performance of rights issuing firms. Therefore, we perform a cross-sectional regression analysis. The announcement period cumulative excess stock return and the post-issue cumulative excess operating performance of firms are used as the dependent variables. The explanatory variables are the ones used to proxy the information asymmetry, the free cash flows and the window of opportunity hypotheses. The regression results are presented in Tables 6 and $7 .^{12}$

We observe in Table 6 (model 1) that the announcement period excess stock return is inversely related to the relative size of the rights issue. In this univariate analysis, the magnitude of the issue-size coefficient is -0.11 and it is also statistically significant ( $t$ value $=-2.04$ ). The finding indicates that as the relative size of the rights issue increases, a larger decline in the stock price takes place. The result supports the prediction of the information asymmetry hypothesis that larger equity issues signal more negative information thereby depressing stock prices more. Bohren et al. (1997) find similar results for Norwegian rights issues.

\footnotetext{
${ }^{12}$ For the sake of brevity, Table 7 reports results for the levels of operating performance. By performing similar regressions to explain changes in operating performance, the results do not change materially.
} 
We find a significant positive relationship between the announcement period excess stock return and the relative offer price. ${ }^{13}$ The univariate regression coefficient of the variable is 0.31 (model 2 ) and is statistically significant ( $\mathrm{t}$-value $=2.22$ ). The explanatory power of the issue-price variable is larger than that of the issue-size variable. The result is again consistent with the information asymmetry hypothesis which posits that higher quality firms use higher subscription price, or smaller discounts, as a signal of quality, and therefore, experience a less negative price decline. The finding of a significant relationship may at first sight appear surprising because the offer price in a rights issue is theoretically considered to be irrelevant. However, as suggested by Eckbo and Masulis (1995), this argument does not necessarily hold in a world of asymmetric information. Prior studies (e.g. Slovin et al., 2000) also report significant relationship between offer price discount and announcement period stock returns. When both the issue-size and the issue-price variables are used in a bivariate regression framework (model 3), we obtain similar negative and positive coefficients. But, the coefficient of issue-size variable becomes statistically insignificant. This can be explained by the presence of statistically significant correlation between these two explanatory variables. We find that the estimated correlation coefficient is -0.4 and is statistically significant. The issue-price variable is also significantly positively related to post-rights issue operating performance of firms, as can be observed from Table 7. Overall, our results provide full support for the asymmetric information hypothesis.

The overinvestment of free cash flows hypothesis predicts that stock return and operating performance will be positively related with issuing firms' market to book ratio of total assets. The results of models 4 and 5 in Table 6 show that although the coefficient of the market to book ratio of total assets is positive, it is statistically insignificant. ${ }^{14}$ On the other hand, the results presented in Table 7 indicate that the market to book ratio is significantly positively related to various measures of operating performance. The regression coefficient

\footnotetext{
${ }^{13}$ The issue-price variable as reported in Table 7 is measured with respect to the stock price prevailing on the day before the issue announcement. If we scale with respect to other period's stock prices, the results remain basically unchanged.

${ }^{14} \mathrm{We}$ also used other specifications of multivariate regressions and the variable remains statistically insignificant.
} 
is around 0.2 and remains stable among different specifications. The observed performance decline experienced by rights issuing firms receives, at least, partial support from the overinvestment of free cash flows hypothesis.

To determine whether corporate managers utilize the opportunity of favorable economic conditions to issue new equity, we investigate the relationship between announcement period stock return and the annual growth rate of gross domestic product. As reported in model 5 of Table 6, we observe that the GDP growth rate is insignificantly related to stock returns. We also examine the relationship between the GDP growth rate and the operating performance of rights issuing firms. All but one regression coefficients are found to be statistically insignificant. Conducting tests using other proxy variables in both univariate and multivariate framework do not produce any significant result. The findings, therefore, fail to support the window of opportunity hypothesis.

In summary, the cross-sectional regression analysis indicates that the decline in both stock returns and operating performance of rights issuing firms is significantly related to the degree of information asymmetry between corporate managers and investors. We find that firms with higher information asymmetry experience larger decline in stock and operating performance. We also observe that rights offering firms with higher amount of free cash flows experience lower operating performance. The evidence is supportive of the view that rights issues may lead to more overinvestments by corporate managers. We do not, however, find any empirical evidence that the underperformance of rights issuing firms is caused by managers utilization of opportunistic timing.

\section{SUMMARY AND CONCLUSIONS}

We study a sample of equity rights offerings in the Netherlands and investigate if stock market valuation effect at issue announcement is consistent with subsequent operating performance of firms. Our empirical analysis reveals that stock prices decline significantly on the announcement of rights issues. It indicates that stock holders interpret equity rights issue as a negative news. The finding is consistent with several prior studies. We also 
observe that the stock market effect of rights offerings is diffused over a longer time period that encompasses the release of issue prospectus and the trading of rights. Additional examination shows that rights are actively traded during the subscription period. Rights trading reaches the maximum as the subscription period comes to the end. We also observe that a gradual decline in stock return takes place throughout the period of rights trading.

We then investigate if the decline in stock price reflects subsequent decline in operating performance of firms conducting rights issues. Therefore, we evaluate diverse return on assets and return on sales variables for several years following rights offerings. Our analysis of the operating performance of issuing firms shows a significant worsening from one year up to five years after rights issues. The result is robust to different ways of measuring operating performance. It indicates that the stock market was able to anticipate already at the time of rights issue announcement the subsequent change in operating performance of issuing firms. Our study thus provides direct evidence on the link between stock market response to an information event and the resulting change in operating performance.

We also explore several explanations for the observed decline in stock returns as well as operating performance. Cross-sectional regression analysis shows that the relative offer price is significantly positively related to stock return and operating performance. The result is robust to alternative model specifications. We observe full empirical support for the prediction of the information asymmetry hypothesis: firms with greater information asymmetry (i.e. larger offer price discount) exhibit larger decline in performance. In addition, we find partial support for the prediction of the free cash flows hypothesis: firms with higher possibilities of overinvestment of free cash flows (i.e. lower market to book ratio) exhibit larger decline in performance. However, we do not find any evidence for the window of opportunity hypothesis as being an important motive to issue new equity. Stock return and operating performance of firms are not found to be significantly related with any of the variables representing favorable economic condition. 
Overall, this study contributes to the large body of empirical research that attempts to test predictions from the corporate finance literature. It provides direct evidence on the link between stock performance on the capital market and operating performance on the real market. Furthermore, the study sheds light on the flotation method of rights offering by analyzing the rights trading period in detail. It also complements prior studies which investigate the stock and operating performance of non-rights equity issues. In view of the available evidence on the effect of seasoned equity issues in general, we conclude that the effect of rights issues is not qualitatively different from non-rights issues. Both equity offering methods convey qualitatively similar information and produce qualitatively similar changes in stock price and operating performance. However, comparing our results with extant literature, we can conclude that the magnitude of decline in stock price and firm performance is smaller for firms conducting rights issues. 


\section{$\underline{\text { References }}$}

Ambarish, R., K. John and J. Williams, 1987, Efficient signalling with dividends and investments, Journal of Finance 52, 321-343.

Armitage, S., 1998, Seasoned equity offers and rights issues: a review of the evidence, European Journal of Finance 4, 29-59.

Armitage, S., 2000, The direct costs of UK rights issues and open offers, European Financial Management 6, 57-68.

Barber, B. and J. Lyon, 1996, Detecting abnormal operating performance: the empirical power and specification of test statistics, Journal of Financial Economics 41, 359-399.

Bayless, M. amd S. Chaplinsky, 1996, Is there a window of opportunity for seasoned issuance?, Journal of Finance 60, 253-278.

Berglund, T., E. Liljeblom and B. Wahlroos, 1987, Stock price reactions to announcements of stock dividends and rights issues: a test of liquidity and signalling hypotheses on the Helsinki Stock Exchange, Finance 8, 109-132.

Bohren, O., B. Espen Eckbo and D. Michalsen, 1997, Why underwrite rights offerings? Some new evidence, Journal of Financial Economics 46, 223-261.

Choe, H., R. Masulis and V. Nanda, 1993, Common stock offerings across the business cycle: theory and evidence, Journal of Empirical Finance 1, 3-33.

Eckbo, E. and R. Masulis, 1995, Seasoned equity offerings: a survey, in Jarrow, R., Maksimovic, V. Ziemba, W. (eds.), Finance, Handbooks in Operations Research and Management Science, North-Holland, Amsterdam, pp. 1017-1072.

Eckbo, E. and R. Masulis, 1992, Adverse selection and the rights offer paradox, Journal of Financial Economics 32, 293-332.

Eckbo, E., R. Masulis and O. Norli, 2000, Seasoned public offerings: resolution of the 'new issues puzzle', Journal of Financial Economics 56, 251-291.

Gajewski, J-F. and E. Ginglinger, 1998, Seasoned equity issues in a closely held market: evidence from France, Working Paper.

Hansen, R., 1989, The demise of the rights issue, Review of Financial Studies 1, 289-309.

Jensen, M., 1986, Agency costs of free cash flow, corporate finance, and takeovers, American Economic Review 76, 323-329.

De Jong, A. and C. Veld, 2001, An empirical analysis of incremental capital structure decisions under managerial entrenchment, Journal of Banking and Finance, forthcoming. 
Jung, K., Y. Kim and R. Stulz, 1996, Timing, investment opportunities, managerial discretion, and the security issue decision, Journal of Financial Economics 42, 159-185.

Kang, J., Y. Kim and R. Stulz, 1999, The underreaction hypothesis and the new issue puzzle: evidence from Japan, Review of Financial Studies 12, 519-534.

Kang, J. and R. Stulz, 1996, How different is Japanese corporate finance? An investigation of the information content of new security issues, Review of Financial Studies 9, 109-139.

Kothare, M., 1997, The effects of equity issues on ownership structure and stock liquidity: a comparison of rights and public offerings, Journal of Financial Economics 43, 131-148.

Lee, I. and T. Loughran, 1998, Performance following convertible bond issuance, Journal of Corporate Finance 4, 185-207.

Levis, M., 1995, Seasoned equity offerings and the short- and long-run performance of initial public offerings in the UK, European Financial Management 1, 125-146.

Loderer, C. and H. Zimmermann, 1988, Stock offerings in a different institutional setting: the Swiss case, 1973-1983, Journal of Banking and Finance 12, 353-378.

Loughran, T. and J. Ritter, 1997, The operating performance of firms conducting seasoned equity offerings, Journal of Finance 52, 1823-1850.

Loughran, T. and J. Ritter, 1995, The new issue puzzle, Journal of Finance 50, 23-51.

Marsh, P., 1979, Equity rights issues and the efficiency of the UK stock market, Journal of Finance 34, 839-862.

McLaughlin, R., A. Safieddine and G. Vasudevan, 1996, The operating performance of seasoned equity issuers: free cash flow and post-issue performance, Financial Management 25, 41-53.

Myers, S. and N. Majluf, 1984, Corporate financing and investment decisions when firms have information investors don't have, Journal of Financial Economics 13, 187-221.

Singh, A., Layoffs and underwritten rights offers, Journal of Financial Economics 43, $105-130$.

Smith, C., 1977, Alternative methods for raising capital: rights issues versus underwritten offerings, Journal of Financial Economics 5, 273-307.

Slovin, M., M. Sushka and K. Lai, 2000, Alternative flotation methods, adverse selection and ownership structure: evidence from seasoned equity issuance in the U.K., Journal of Financial Economics 57, 157-190. 
Spiess, D. and J. Affleck-Graves, 1995, Underperformance in long-run stock returns following seasoned equity offerings, Journal of Financial Economics 38, 243-267.

Tsangarakis, N., 1996, Shareholder wealth effects of equity issues in emerging markets: evidence from rights offerings in Greece, Financial Management 25, 21-32. 


\section{$\underline{\text { Table } 1}$}

\section{Selected descriptive statistics}

This table reports summary statistics for issue-characteristics such as issue-size and issue-price and some firm characteristics related to a sample of 58 equity rights offerings. Issue-size is expressed as relative to the market value of equity on the day before the announcement. Issue-price is expressed as relative to the closing stock price of one day and three days before the issue announcement as well as the average of closing stock prices for ten days before the announcement. Book value of total assets and market value of equity are expressed in millions of Euros. Market-to-book ratio is defined as the sum of market value of equity and book value of debt divided by book value of total assets. All firm characteristics are as of the issue year.

\begin{tabular}{|l|c|c|c|c|c|}
\hline Variable & Mean & Median & $\begin{array}{c}\text { Standard } \\
\text { deviation }\end{array}$ & Maximum & Minimum \\
\hline Issue-size & 0.212 & 0.159 & 0.184 & 0.990 & 0.012 \\
\hline Issue-price (-1) & 0.868 & 0.877 & 0.098 & 1.00 & 0.568 \\
\hline Issue-price (-3) & 0.873 & 0.885 & 0.099 & 1.00 & 0.571 \\
\hline Issue-price (-1, -10) & 0.872 & 0.883 & 0.099 & 1.00 & 0.569 \\
\hline Book value of total assets & 623 & 178 & 1023 & 4367 & 3 \\
\hline Market value of equity & 349 & 113 & 623 & 3093 & 9 \\
\hline Market-to-book ratio & 1.05 & 0.99 & 0.27 & 2.09 & 0.65 \\
\hline
\end{tabular}


$\underline{\text { Table } 2}$

\section{Excess stock returns around announcement of equity rights issues}

The table shows cumulative excess stock returns for various periods surrounding the announcement (day 0) of equity rights issues. Excess returns are calculated after adjusting for each stock's systematic risk estimated from the Market Model, and are expressed in percentages. The t-statistic and the Wilcoxon signed rank statistics are used to test statistical significance of mean and median returns, respectively. The symbols $*$ and $* *$ indicate statistical significance at the $10 \%$ and $5 \%$ level, respectively.

\section{Panel A: Mean excess returns}

\begin{tabular}{|c|c|c|}
\hline Period & Excess return & t-statistic \\
\hline$-60,-1$ & 3.27 & $1.98^{*}$ \\
\hline $0,+1$ & -2.79 & $-7.89^{* *}$ \\
\hline$+2,+30$ & -2.55 & $-1.76^{*}$ \\
\hline $0,+30$ & -5.34 & $-3.71^{* *}$ \\
\hline
\end{tabular}

\section{Panel B: Median excess returns}

\begin{tabular}{|c|c|c|}
\hline Period & Excess return & z-statistic \\
\hline$-60,-1$ & 0.21 & 0.91 \\
\hline $0,+1$ & -1.76 & $3.09^{* *}$ \\
\hline$+2,+30$ & -4.08 & $2.18^{* *}$ \\
\hline $0,+30$ & -5.66 & $3.01^{* *}$ \\
\hline
\end{tabular}


$\underline{\text { Table } 3}$

\section{Excess stock returns during the rights trading period}

The table shows average and cumulative average excess stock returns following the start of rights trading. Day 1 is the starting date of rights trading, which is approximately two to three weeks after the announcement of rights issue. All other days are measured relative to the starting date of rights trading. The total duration of rights trading varies across firms. Excess stock returns are calculated based on Market Model risk adjustments and are expressed in percentages.

\begin{tabular}{|c|c|c|c|}
\hline Trading day & Excess return & \% Negative & Cumulative excess return \\
\hline 1 & 0.689 & 38 & 0.689 \\
\hline 2 & -0.209 & 53 & 0.481 \\
\hline 3 & -0.062 & 60 & 0.419 \\
\hline 4 & -0.199 & 64 & 0.220 \\
\hline 5 & -0.682 & 69 & -0.462 \\
\hline 6 & -0.452 & 56 & -0.914 \\
\hline 7 & -0.378 & 69 & -1.292 \\
\hline 8 & -0.059 & 60 & -1.351 \\
\hline
\end{tabular}




\section{$\underline{\text { Table } 4}$}

\section{Abnormal levels of operating performance of companies subsequent to rights issues}

The table reports median abnormal levels of operating performance of firms for five years after rights issue with Year 0 used as the fiscal year of rights issue. The figures are expressed in percentages. Abnormal measures are calculated as the difference in performance between issuing firm and median non-issuing firm. Panel A reports four different return on assets (ROA) measures: the ratios of net income to average total assets, cash flow (net income plus depreciation plus the change in current assets excluding the change in cash minus the change in current liabilities plus the change in current maturities of long-term debt) to the average of total assets, earnings before interest and taxes (EBIT) to the average of total assets, and earnings before interest, taxes and depreciation and amortisation (EBITDA) to average total assets. Panel B reports four different return on sales (ROS) measures calculated using the same statistics as above but dividing by the average of total sales in lieu of the average of total assets. The symbols * and ** denote significance at the $10 \%$ and $5 \%$ level (two-tailed), respectively, as indicated by the Wilcoxon signed-rank statistic.

\section{Panel A: ROA measures}

\begin{tabular}{|l|c|c|c|c|c|c|}
\hline & Year 0 & Year 1 & Year 2 & Year 3 & Year 4 & Year 5 \\
\hline Net income / Total assets & -0.5 & -0.5 & $-1.3^{*}$ & $-1.1^{*}$ & -1.2 & $-1.4^{*}$ \\
\hline Cash flow / Total assets & -1.5 & -0.3 & $-3.2^{*}$ & -2.0 & -1.2 & -0.9 \\
\hline EBIT / Total assets & -0.4 & 0.3 & -0.3 & -0.1 & $-2.1^{* *}$ & $-2.1^{*}$ \\
\hline EBITDA / Total assets & 0.3 & -0.2 & $-1.3^{*}$ & -2.1 & $-2.2^{* *}$ & -3.3 \\
\hline Number of observations & 55 & 55 & 55 & 52 & 51 & 46 \\
\hline
\end{tabular}




\section{Panel B: ROS measures}

\begin{tabular}{|l|c|c|c|c|c|c|}
\hline & Year 0 & Year 1 & Year 2 & Year 3 & Year 4 & Year 5 \\
\hline Net income / Total sales & -0.1 & -0.4 & -0.7 & $-0.9^{*}$ & -1.0 & $-1.1^{*}$ \\
\hline Cash flow / Total sales & -1.3 & 0.1 & $-1.9^{* *}$ & $-1.7^{*}$ & -1.4 & -1.1 \\
\hline EBIT / Total sales & 0.5 & 0.4 & -0.6 & $-1.4^{*}$ & $-1.7^{*}$ & $-1.6^{*}$ \\
\hline EBITDA / Total sales & 0.5 & 1.6 & $-1.8^{*}$ & -1.7 & $-2.0^{*}$ & $-2.0^{*}$ \\
\hline Number of observations & 55 & 55 & 55 & 52 & 51 & 46 \\
\hline
\end{tabular}




\section{$\underline{\text { Table } 5}$}

\section{Abnormal change in operating performance of companies subsequent to rights issues}

The table reports year-to-year median abnormal percentage changes in operating performance of firms for five years after rights issue with Year 0 used as the fiscal year of rights issue. Abnormal measures are calculated as the difference in performance between issuing firm and median non-issuing firm. Panel A reports four different return on assets (ROA) measures: the ratios of net income to average total assets, cash flow (net income plus depreciation plus the change in current assets excluding the change in cash minus the change in current liabilities plus the change in current maturities of long-term debt) to the average of total assets, earnings before interest and taxes (EBIT) to the average of total assets, and earnings before interest, taxes and depreciation and amortization (EBITDA) to average total assets. Panel B reports four different return on sales (ROS) measures calculated using the same statistics as above but dividing by the average of total sales in lieu of the average of total assets. The symbols $*$ and $* *$ denote significance at the $10 \%$ and $5 \%$ level (two-tailed), respectively, as indicated by the Wilcoxon signed-rank statistic.

\section{Panel A: ROA measures}

\begin{tabular}{|l|c|c|c|c|c|c|}
\hline & $\begin{array}{c}\text { Year -1 to } \\
\text { Year 0 }\end{array}$ & $\begin{array}{c}\text { Year 0 to } \\
\text { Year 1 }\end{array}$ & $\begin{array}{c}\text { Year 1 to } \\
\text { Year 2 }\end{array}$ & $\begin{array}{c}\text { Year 2 to } \\
\text { Year 3 }\end{array}$ & $\begin{array}{c}\text { Year 3 to } \\
\text { Year 4 }\end{array}$ & $\begin{array}{c}\text { Year 4 to } \\
\text { Year 5 }\end{array}$ \\
\hline Net income / Total assets & 0.1 & -0.5 & 0.1 & 0.1 & -0.4 & 0.2 \\
\hline Cash flow / Total assets & -0.3 & 0.1 & $-1.6^{*}$ & 2.1 & -0.3 & 1.4 \\
\hline EBIT / Total assets & 0.2 & -0.7 & -0.8 & -0.4 & -0.3 & -0.3 \\
\hline EBITDA / Total assets & 0.2 & $-0.4^{* *}$ & -1.0 & -0.1 & -0.2 & -0.1 \\
\hline Number of observations & 51 & 55 & 54 & 52 & 51 & 45 \\
\hline
\end{tabular}


Panel B: ROS measures

\begin{tabular}{|l|c|c|c|c|c|c|}
\hline & $\begin{array}{c}\text { Year -1 to } \\
\text { Year 0 }\end{array}$ & $\begin{array}{c}\text { Year 0 to } \\
\text { Year 1 }\end{array}$ & $\begin{array}{c}\text { Year 1 to } \\
\text { Year 2 }\end{array}$ & $\begin{array}{c}\text { Year 2 to } \\
\text { Year 3 }\end{array}$ & $\begin{array}{c}\text { Year 3 to } \\
\text { Year 4 }\end{array}$ & $\begin{array}{c}\text { Year 4 to } \\
\text { Year 5 }\end{array}$ \\
\hline Net income / Total sales & 0.3 & -0.1 & -0.1 & -0.1 & $-0.7^{*}$ & -0.1 \\
\hline Cash flow / Total sales & -0.6 & 0.5 & -1.2 & 1.3 & -1.6 & 0.3 \\
\hline EBIT / Total sales & 0.0 & -0.3 & $-0.6^{*}$ & -0.2 & -0.2 & $-0.8^{*}$ \\
\hline EBITDA / Total sales & 0.1 & $-0.4^{* *}$ & $-0.9^{* *}$ & -0.5 & $-0.6^{* *}$ & $-0.8^{* *}$ \\
\hline Number of observations & 51 & 55 & 54 & 52 & 51 & 45 \\
\hline
\end{tabular}




\section{Table 6}

\section{Cross-sectional regressions of excess stock return on various explanatory variables}

The table reports results where the two-day announcement period Market Model risk-adjusted excess stock return is regressed on various explanatory variables. The explanatory variables are: issue-size $=$ the monetary amount of rights issue / market value of equity on the day before announcement; issue-price = the offer price / stock price on the day before the issue announcement; $\mathrm{M} / \mathrm{B}=$ the ratio of market to book value of total assets; GDP $=$ a dummy variable set to 1 if the issue occurs in years of relatively high growth rate of GDP. White heteroskedasticity-adjusted t-statistics are presented in parentheses below the regression coefficients. The symbols * and $* *$ indicate statistical significance at the $10 \%$ and $5 \%$ level, respectively.

\begin{tabular}{|c|c|c|c|c|c|c|}
\hline Model & Intercept & Issue-size & Issue-price & $\mathrm{M} / \mathrm{B}$ & GDP & Adj. $R^{2}$ \\
\hline 1 & $\begin{array}{c}-0.01 \\
(-0.49) \\
\end{array}$ & $\begin{array}{c}-0.11 \\
(-2.04)^{* *}\end{array}$ & & & & 0.06 \\
\hline 2 & $\begin{array}{c}-0.29 \\
(-2.39)^{* *}\end{array}$ & & $\begin{array}{c}0.31 \\
(2.22)^{* *}\end{array}$ & & & 0.17 \\
\hline 3 & $\begin{array}{c}-0.25 \\
(-1.88)^{*}\end{array}$ & $\begin{array}{c}-0.05 \\
(-1.02) \\
\end{array}$ & $\begin{array}{c}0.27 \\
(1.82)^{*} \\
\end{array}$ & & & 0.17 \\
\hline 4 & $\begin{array}{c}-0.40 \\
(-3.97)^{* *}\end{array}$ & & $\begin{array}{c}0.42 \\
(3.40)^{* *}\end{array}$ & $\begin{array}{c}0.01 \\
(0.16) \\
\end{array}$ & & 0.26 \\
\hline 5 & $\begin{array}{c}-0.34 \\
(-4.38)^{* *}\end{array}$ & $\begin{array}{c}-0.02 \\
(-1.35)\end{array}$ & $\begin{array}{c}0.31 \\
(3.50)^{* * *}\end{array}$ & $\begin{array}{c}0.01 \\
(0.27)\end{array}$ & $\begin{array}{c}0.01 \\
(0.25)\end{array}$ & 0.24 \\
\hline
\end{tabular}




\section{$\underline{\text { Table } 7}$}

\section{Cross-sectional regressions of excess operating performance on various explanatory variables}

The table reports results where the cumulative abnormal level of operating performance for five years after rights issue is regressed on various explanatory variables. The explanatory variables are: issue-size $=$ the monetary amount of rights issue / market value of equity on the day before announcement; issue-price = the offer price / stock price prevailing one day before the issue announcement; $\mathrm{M} / \mathrm{B}=$ the ratio of market to book value of total assets; GDP $=$ a dummy variable set to 1 if the issue occurs in years of relatively high growth rate of GDP. White heteroskedasticity-adjusted t-statistics are presented in parentheses below the regression coefficients. The symbols * and ** indicate statistical significance at the $10 \%$ and $5 \%$ level, respectively.

\begin{tabular}{|l|c|c|c|c|c|c|}
\hline Dependent variable & Intercept & Issue-size & Issue-price & M/B & GDP & Adj. $\mathrm{R}^{2}$ \\
\hline Net income / Total assets & -1.01 & -0.03 & 0.82 & 0.18 & 0.03 & 0.14 \\
\hline Cash flow / Total assets & $-2.52)^{* *}$ & $(-0.14)$ & $(2.20)^{* *}$ & $(2.00)^{* *}$ & $(0.53)$ & 0.13 \\
\hline EBIT / Total assets & $(-1.57)$ & $(-0.27)$ & $(1.08)$ & $(1.45)$ & $(1.94)^{*}$ & 0.09 \\
\hline EBITDA / Total assets & -0.76 & -0.17 & 0.54 & 0.21 & 0.06 & 0.14 \\
\hline
\end{tabular}

